\title{
Political Rights of the Citizen in the 2014 Election and the Democracy Index in West Java: The Importance to Strengthen the Accessibilities
}

\author{
Asep Abdul Sahid Universitas Islam Negeri Sunan Gunung Djati, Indonesia \\ Mohd. Solahuddin Bin Shahruddin Universiti Teknologi MARA, Malaysia
}

\begin{abstract}
Political rights of citizen are an important aspect of Indonesian Democracy Index (IDI). However, in the 2014 Election, this aspect, particularly IDI of West Java, showed the lowest number. One of the efforts have been made by Election organizers to fulfill the political rights of citizen is to make accessibility as the principle of Election through Election Commission Regulation (PKPU). This study addresses why the aspect of the fulfillment of political rights of citizen is low in IDI; and how the principle of accessibility in to fulfill political rights of citizen is being implemented. The corpus of this study is document of IDI West Java Province and information of online media. The results indicate that; first, the implementation of the fulfillment of the political rights of citizen in the 2014 Election in West Java had a number of obstacles, namely the regulation of the accessibility principle is still limited; the lack of data of persons with disabilities; and the weakness of Election organizers concerning voters with disabilities. And secondly, efforts to implement the principle of accessibility by Election organizers are mostly concentrated in the election period implementation process, while the implementation process of the pre-election and post-election periods tends to be ignored.
\end{abstract}

Keywords:

Political Rights of Citizen; Indonesia Democracy Index; Accessibility Principles; Equal Acces

\section{INTRODUCTION}

One of the ways to fulfill citizen political rights is to hold general election event; both legislative and executive

Asep Abdul Sahid is a lecturer and researcher at Department of Political Science-Universitas Islam Negeri Sunan Gunung Djati, Jl. A.H. Nasution No.105, Cipadung, Cibiru, Kota Bandung, Jawa Barat, Indonesia. His research interest about representative politics and society. (asepsahidgatara@uinsgd.ac.id)

Mohd. Solahuddin bin Shahruddin is a lecturer and researcher at Academy of Contemporary Islamic Studies (ACIS)-Universiti Teknologi MARA, Shah Alam, Selangor, Malaysia. His research interest about Islam and politics. (msolahuddin@salam.uitm.edu.my)

We are thankful for the insightful comments of the two anonymous reviewers for this paper. (national leadership and local government leadership) positions. The State of Indonesia define and position general election as people sovereignty implementation with its embedded characteristics are as follows; direct, general, free, confidential, and just within the Republic of Indonesia based on Pancasila and Republic of Indonesia 1945 Constitution.

Direct means people as voter do have right to directly give their ballot accordingly to their own conscience 
without any intermediary. While general has meaning that the constitution conserves the opportunity which applies to every citizen without any discrimination against certain ethnicity, religion, race, group, gender, locality, occupation, and social status. Every citizen who has right to vote is free to determine his/her choice without any pressure and coercion from any part. In giving their ballot, the voter is ensured that his/her choice will not be known by any part. The voter gives his/her choice through the ballot without anyone knowing what the choice is. Every voter and general election participant will receive equal treatment, and will be free from any fraud from any part (Law No. 8 2012 on DPR, DPD, and DPRD General Election).

In the general election event, besides possessing the right to vote, civil society also has the right to be candidate (Schwarz, 2018). Further, the people's political rights manifests in equal position before the regime or general election authority, especially in terms of equality of every citizen in accessing every kinds of general election's procedures and essences.

To meet all of the people's political rights, especially those of the disabled people, the accessibility principle has been added to the 2014 general election execution. The principle is confirmed through the General Election Committee Regulation/Peraturan Komisi Pemilihan Pemilu (PKPU) Number 26 year 2013 on Voting and Vote Calculation on the Voting Site in General Election of People's Representative Assembly, Regional Representative Council, Province Regional People's Representative Assembly, Regency Regional People's Representative Assembly (as per alteration through KPU Regulation Number 5 year 2014 on Alteration on KPU Regulation Number 26 year 2013 on Voting and Vote Calculation on the Voting Site in General Election of People's Representative Assembly, Regional Representative Council, Province Regional People's Representative Assembly, Regency Regional People's Representative Assembly).

Accessibility principle is one of the general election execution guidances in voting and vote counting. Beside accessibility principle, there are also other principles such as law certainty, orderliness, general interest, openness, proportionality, and professionalism. Accessibility principle is more directed toward people with limited access. It is because they have special needs, for example, people who are physically 
disabled, being deaf, being blind, and to explain the obstacles and challenges it other kind of disabilities. They have equal faces.

political rights with other people groups.

Unfortunately, along with the THEORETICAL PERSPECTIVES accessibility principle addition in 2014 Research Method

general election, KPU also issued policy With the theoretical basis as on braille template limitation. KPU only aforementioned above, the conceptual provides braille template for Regional study on accessibility principle in citizen Representative Council (DPD) for the political rights fulfillment with its relation blind people. There are no braille template with Indonesia Democracy Index in 2014 for People's Representative Assembly general election is using qualitative (DPR) and Regional People's approach with descriptive type analysis. Representative Assembly (DPRD, at The descriptive type relates to a study that Province and Regency/City level) aims to describe general election authority (Perdana, 2014). Whereas, the previous efforts in strengthening accessibility general election in 2009 the braille principle. This type of study also to template was available for every kinds of identify the obstacles in implementing ballot. Meanwhile, for other disabled accessibility principle of 2014 general group such as deaf people, physically election in fulfilling the citizen political disabled people, KPU provides several rights, especially those of the people with guides on the voting site (TPS/Tempat disability.

Pemungutan Suara).

As for the study data is the Indonesia

In particular, this study finds Democracy Index of West Java province accessibility principle in 2014 general that is archived by Statistics Indonesia election through West Java citizen (Badan Pusat Statistik/BPS) of West Java political rights fulfillment reflected in West province. Online mass media news are Java Province Democracy Index. The also resources for study data. Data analysis on citizen political rights collection technique is employing fulfillment execution in 2014 general literature review on certain news and election aims not only to describe institutional documentation. The collected accessibility access strengthening but also data then processed and analyzed with descriptive qualitative analysis technique. 


\section{LITERATURE REVIEW}

\section{Previous Studies}

Based on the writer's experience and knowledge, until this day there has been no existing comprehensive study on accessibility principle in citizen political rights fulfillment, especially within 2014 general election in West Java. It is even rarer when it is analyzed with the correlation with Indonesia Democracy Index (Junaenah, 2015). The reason of low contribution of people's political rights to the Indonesia Democracy Index in West Java and the process of accessibility principle execution are yet to discover and to analyze deeply.

Citizen's political rights is one of the three aspects of Indonesia Democracy Index (civil freedom and democracy institutions aspects) and accessibility issues (eg. Lack or absence of facilities so that people with access limitation cannot use their voting right) is one of the important indicators. Citizen involvement in political processes is definitely required to strengthen nation's democracy construction (Bengtsson and Chritensen, 2016). Therefore, opening as wide as possible access to political world is assurance for citizen to be enthusiast to participate in politics.
Among the rare academic study in this topic, there is dissertation written by Yayat Hidayat (2016), in Universitas Padjajaran, Bandung city under the title Accessibility in 2014 Legislative General Election for the Disabled People in West Java. In his study, Yayat Hidayat analyzed the general election accessibility to be the Zeitgeist in executing general election for electing regent, mayor, governor, and president.

To meet the demand, Yayat argued that equality of every citizen must be prioritized in the future. To this date, Yayat added, people with disabilities are very vulnerable to abuse in using their voting right. Because of that reason, he hoped the research could be a reference to execute general election. However, Yayat did not give special attention on obstacles in disabled people rights fulfillment, and how it contributes to the Indonesia Democracy Index in West Java province.

Mario Merly also studied the accessibility principle in 2014 general election. The study titled as 2014 General Election and Its Implication on Political Resilience (Study on College Student with Disabilities Perception in Diffable Service Center at UIN Sunan Kalijaga Yogyakarta) (Merly, 2015). The study viewed 
accessibility that was still a problem in 2014 general election. The study was a descriptive qualitative research with interview and observation as data collection method.

Merly used purposive sampling to select informant or research subject to suit the research criteria. The informants were students with disabilities at Universitas Islam Negeri (UIN) Sunan Kalijaga Yogyakarta. The collected data in the research was the perception of the student with disabilities. The research concluded that students with disabilities were giving bad judgment on laws implementation that already regulated accessibility. The general election authority had failed to implement the regulatory ground to design accessible general election for the disabled people. However, the accessibility policy is neglected and is not receiving the government attention. Eventually, the political attitude of the students with disabilities is prone to shift into distrust towards the government. The implication is it could lead to a vulnerable situation where political resilience is affected, because without public trust the society building will lose one of its fundamental key aspects that will hamper democratic society construction.
The studies on accessibility principle in 2014 general election above are not significantly related with political rights aspect. Therefore, this study is different from the aforementioned studies since it coheres with citizen right fulfillment carried out by the authority who administer the general election. Besides, Merly viewed the accessibility aspect from its implication to the political resilience. While this study focuses on the implication of Indonesia Democracy Index of West Java province.

One of the rare academic studies on the disabled people political right fulfillment in general election is a research by Mugi Riskiana Halalia (2016) in the work under the title The Rights Fulfillment of the People with Disabilities according to Law Number 8 year 2016 on People with Disabilities by Komisi Pemilihan Umum (KPU) Yogyakarta City. Halalia analyzed the political rights fulfillment efforts coherence in general election by the authority in this case KPU of Yogyakarta city with the implementation of Law No. 8 year 2016 on People with Disabilities, within which regulates political rights of the disabled people.

The study shows that the efforts by KPU of Yogyakarta city in political rights fulfillment of the disabled people are 
already in accordance with the Law No. 8 year 2016 on People with Disabilities. The efforts manifest in honoring the value of equality and sameness of opportunity for the disabled to participate in political life. Nevertheless, Halalia gave not that in the efforts were not comprehensively fulfilling the political rights of the disabled in the general election.

The efforts of KPU of the Yogyakarta city in fulfilling the disabled people political rights in general election are; maximize the data building of the voter with disabilities, to give socialization and simulation about the political rights equality to the disabled and to serve the disabled in general election (Mahan, 2018). People with disabilities involvement by recruiting Democracy Volunteer some of whome were disabled people as a part of committee in the general election executive structure, means and infrastructure provision for the accessible voting site (TPS).

Next, a study by Ibrahim (2017) under the title Measuring the Depth of Democracy Measurement, Indonesia Democracy Index (IDI): Substantive Notes from Bangka Belitung. Ibrahim studied ID as the democracy measurement tool in Indonesia to read achievements and to compose planning program for political development. The main issue was in the methodology that eventually connected with real-world democracy situation representation in regions of Indonesia. Ibrahim study has two main focuses, methodology discourse, and notes on chosen consolidation option to integrate IDI result as database and political development orientation. Employing qualitative methodology, and interview, observation, and documentation as data collection methods, Ibrahim found that there are problems on methodological substance on data collection technique, data source distribution aspect, practical concept difference in data understanding, to standard homogenization that lacks attention on regional diversity on various demographic characteristics. At the same time, IDI faces IDI result consolidation options within the context dissemination and its integration as one of the instruments in development planning. Ibrahim study tried to debate IDI's method in reading democracy along with the options on consolidation steps.

Ibrahim study's relevance with this study lies on the Indonesia Democracy Index topic. However, there is differentiating context with this study namely problem and main point. This study context is political rights as an 
aspect of Indonesia Democracy Index, and with the low contribution of citizen political rights to Indonesia Democracy Index as the problem, especially in the West Java province. The focus is the lessthan-optimal implementation of accessibility principle in general election.

There are only few academic studies on the political rights fulfillment and its relation to Indonesia Democracy Index (Hyde, 2010; Mietzner, 2012; Winters, 2013). From those studies, it is conclusive that study on the accessibility principle strengthening in political rights fulfilling and its contribution to Indonesia Democracy Index has yet to be found. Thus, this study has its novelty value in political science development, especially on the relation of accessibility principle aspect to citizen political rights and Democracy Index.

Accessibility Principle as the Pillar for Citizen Political Rights Fulfillment and Democracy Index

Studies on political accessibility are more emphasized on how the citizen political rights are optimally fulfilled, they also try to position accessibility principle as one of efforts in improving democracy index. Accessibility principle, according to Law No. 28 year 2002 on Building
Construction, is interpreted as facility provided for every people including people with special needs and elderly to create equality and opportunity in every life aspects and livelihood.

Within that description, there are two kinds of accessibility namely non-physical and physical accessibility. Non-physical accessibility is facility provided for every people to get into and to use the system, and to get out of a system (Jarman and Kafer, 2014). While physical accessibility is facility provided for everyone to get into and to use, and to get out of a building. In the general election context, non-physical accessibility is facility provided for everyone to get series of information, knowledge, and skill in actualizing their voting rights. Non-physical accessibility in general election also called as substantial accessibility. While physical accessibility in general election is facility or convenience provided for everyone to easily use general election facilities. Physical accessibilities in general election also called as procedural accessibility.

Accessible as the root of the word accessibility means as a space that is everyone can enter. Besides, accessible is also defined as information that is everyone can understand (Atkinson et al, 2017). In the study conducted by Cees 
Flinterman (1990), political rights (along physical or mental limitation. From social with civilian rights) is the first 'generation' pathology perspective, the people with of three 'generations' of Human Rights. It disabilities are categorized as vulnerable is a 'classic' generation of human rights. people group. It is because this group is Second generation are consisting of the often overlooked from the reach of various economic, social, and cultural rights. kinds of services. They even often receive While third generation comprises common unjust and discriminatory treatment. This rights, which are recently getting more attention. Those common rights are rights to development, peace, clean environment, one's own natural resources, and one's own cultural heritage.

Above human rights can group is vulnerable because their condition with blindness, deafness, mental disability, physical disability, including people with leprosy.

In Indonesia Democracy Index, they are vulnerable to condition where lack or absence of facility so they (people with comprehensively manifest only in democratic political system. A political system can emphasize the freedom climate for every citizen (freedom to speak, freedom to organize, freedom to believe in any religion, and freedom from fear and poverty). Such supportive climate is very essential for human rights to thrive (Schur et al, 2015). For that reason, it is relevant to say that accessibility and political rights as Indonesia Democracy Index. If accessibility is as the variable of Indonesia Democracy Index, then political rights is as the index' aspects. One of the groups in the society that must get accessibility principle is people with disabilities. A group within society who has special needs, caused by either limited access) cannot use their right to vote. At this point, accessibility in citizen political rights fulfillment acts one of contributors for Indonesia Democracy Index (IDI). IDI is a conceptualization of numbers that show democracy progress in every province in Indonesia based on several aspects of democracy. The progress level is then measured based on implementation and progress of a set of democracy aspects in every province in Indonesia.

In this case, IDI is a unique tool to measure democracy progress. IDI is designed to be sensitive to the vicissitudes of democracy life, since IDI was thoroughly arranged based on evidence so that the description produced reflects 
happening reality. IDI has objective to quantify democracy progress on province level in Indonesia. From that index, one can observe democracy progress of each province according to the three observed and understood aspects. Besides, democracy progress index in a region is also comparable to other region to obtain democracy progress description in provinces all over Indonesia.

Indonesia Democracy Index from year 2009 to 2012 has three aspects, 11 variables, and 28 indicators. The three aspects are; first, civilian freedom with the variables: freedom to organize and to unionize, freedom to speak, freedom to believe, and freedom from discrimination. Second, political rights that comprises variables: right to vote, and right to be candidate, and political participation in decision making and supervising. And third, democracy institution that comprises of free and just general election, the role of DPRD, the role of political party, the role of regional government bureaucracy, and the role of independent court. The backgrounds of IDI are; first, lack of democracy dynamics measurement; second, democracy analyses are often limited to democracy description and explanation in an abstract manner; third, the public do not know well about the ups and downs or democracy degree in Indonesian history; fourth, unknown condition of democracy dimension (competition, participation, and accountability); fifth, weak academic works on democracy improvement in Indonesia lead to unconvincing recommendation to the executives (Taufiq, 2014).

Accessibility principle conception as a part of democracy index pillar above also refers to a study developed by International Foundation for Electoral System (IFES) in cooperation with National Democratic Institute (NDI). The study concept is known as Akses Setara (Equal Access). The concept explains how to involve people with disabilities in the general election and political process (Atkinson et al, 2017). To achieve that explanation, it is important to understand the obstacle on the field and to know the strategy needed. In other word, there is always relation between the method of disability involvement with the obstacles and challenges on the field and strategies.

In general election context, the method comprises every general election cycle namely pre-general election, during general election, and post-general election. In each cycle, there is always obstacles and challenges that can cause 
people with disabilities cannot use their right to vote and right to be candidate. According to NDI and IFES studies above, common obstacles that disabled people face are categorized into several categories. First, stigma from the society: lack of empowerment, lack of capacity. Stigma from the religion/culture. Family shame. Second, discriminative law framework/infrastructure: lack of accessibility at voting site/government office. And third, relatively demeaning approach by decision makers. Some of the obstacles are unique to the respective area (Atkinson et al, 2017).

Unique obstacles are existing at every cycle step of general election. At the pregeneral election step the potential obstacles are as follows. Discriminative law. Voting site is not accessible. The voting committee are not trained to assist the people with disabilities to vote. Difficulty in obtaining national ID card. Voter registration site is not accessible. Educational material for voters and information on vision and mission of each political parties and candidates are not distributed in accessible formats. People with disabilities are not involved as observer. DPO are not experienced in advocating political rights.
Meanwhile, potential obstacles during the general election period are as mentioned below. The supervisor does not monitor the access issue. Political parties neglect important matters for voters with disabilities or recruit candidates with disabilities (Price, 2018). The manifestos of political parties are not in accessible formats. Security officers are not trained to be aware on how providing safe environment for voters with disabilities. The mass media do not distribute information in accessible formats. Complains over inaccessible judgment. Absence of punishment for general election violators.

The potential obstacles after the general election are as follow. People with disabilities are not involved in training process. DPO do not know voters' rights. Citizenship education does not discuss the rights of people with disabilities, and it is not distributed in accessible formats. General election committee criteria for selection is not inclusive towards the disabled.

Alongside the obstacles, there are also several challenges in equal access implementation in every cycle of political process and general election, the examples are as follow. Lack of available data on number and locations of people 


\section{Graph 1. West Java Province Indonesia Democracy Index Dynamics, 2009-2015}

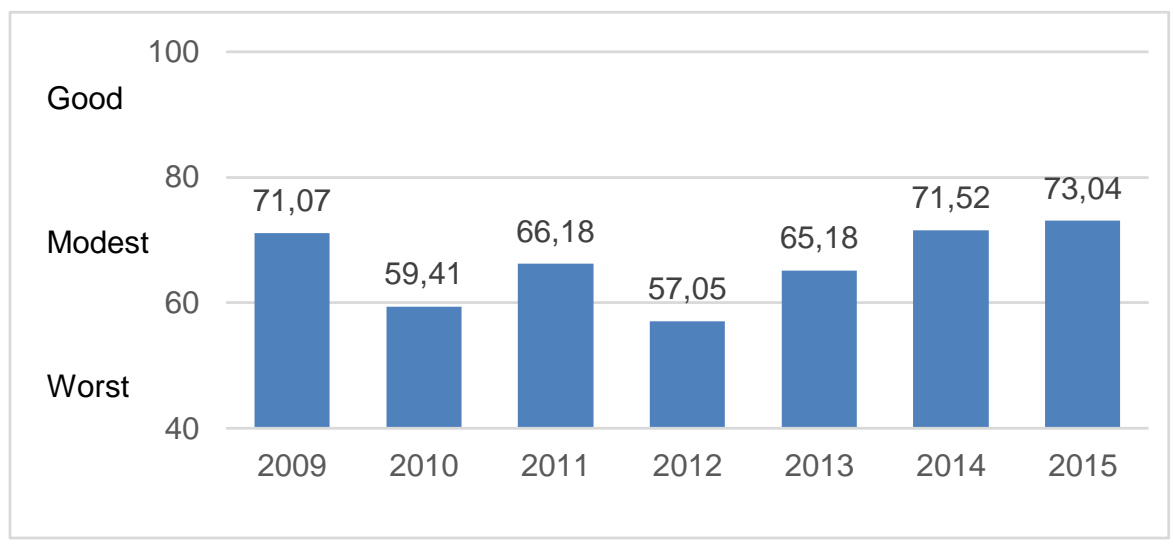

Source: West Java BPS, Official Statistical News No. 46/08/32/Th.XVII, 05 August 2016.

with disabilities. Discrimination by the society. Politically challenging environment where people's participation is halted by the government. The obligation to vote that charges fines onto the disabled people if they do not vote, or automatically erase their names from the voter list. Rare opportunity for people with disabilities to lead. Limited capacity of local BPP to implement accessible technology solution.

To overcome the obstacles and challenges above, according to equal access concept, certain strategies are required with examples are as follows. Empowering the people with disabilities. Supporting government institutions. Involving DPR partners in civil society organization coalition. Helping political parties in implementing reach-out to the disabled people.

\section{RESULT AND DISCUSSION}

Low Contribution towards Democracy Index

Based on the West Java BPS study, Indonesia Democracy Index (IDI) in 2014 is 71,52 (BPS, 2016). The score means democracy life in West Java, if referring to the IDI version of democracy level classification which are; "good" (index $>80$ ), "moderate" (index 60-80), and "bad" (index <60), falls into "moderate" category. The "moderate" democracy climate was during the year 2015. The score rose to 73,04 , although it was not significant since only 1,52 point rise.

West Java IDI index dynamics from 2009 to 2015 is experiencing fluctuation. However, since 2012 to 2015 the West Java democracy climate has been consistently improving from "bad" to "moderate". In 2012, West Java IDI was 57,05 , and in the year 2013 was 65,18 , 
Graph 2. IDI Aspects Dynamics of West Java, 2009-2015

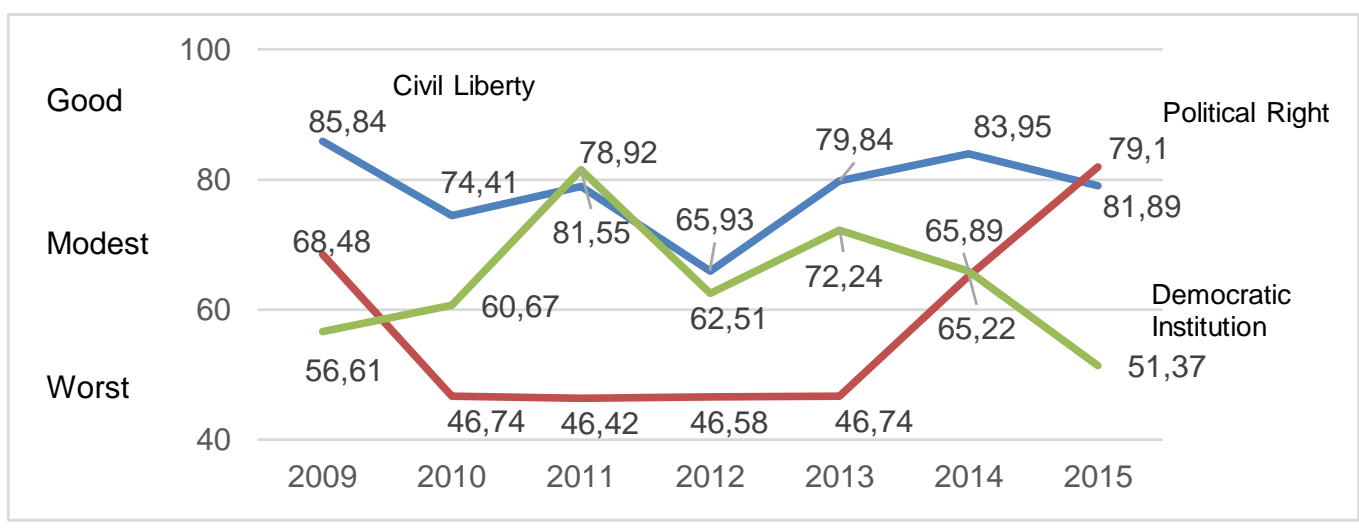

Source: West Java BPS, Official Statistical News No. 46/08/32/Th.XVII, 05 Agustus 2016. West Java Province BPS.

year 2014 was 71,52, and year 2015 with 73,04 . In the previous years, West Java IDI point fluctuated quite sharply. In 2009 West Java IDI was 71,07, and in 2010 59,41, then in 2011 was 66,18. The fluctuation of West Java IDI can be seen from the graph 1.

The graph 1 . explains the fact that democracy life in West Java from year to year is always experiencing dynamics. It has to do with many factors, among them are as follows. Society's freedom degree. Citizen's political rights fulfillment. Democratic institutions existence such as political party, bureaucracy, press, etc. Those three factors of IDI are, as previously mentioned, the aspects of democracy. The three aspects are contributing to the West Java democracy life dynamics. The graph 2 describes the realty.
Referring to the graph 2, West Java IDI in political rights aspect in 2014 had score of 65,22 . That was the lowest score compared to other IDI aspects index score where civilian freedom was 79,10, and democratic institution aspect was 65, 89. The situation suggests that the citizen political rights fulfillment, especially hat of people with disabilities, during the 2014 general election event, did not significantly contribute to the Indonesia Democracy Index improvement of West Java province in the year 2014. Besides, that graph also explains that the accessibility as one of the principles of 2014 general election was not optimally implemented in West Java.

There are two variables and seven indicators as measurement tool from IDI political rights aspects. Those two variables are right to vote and right to be candidate with the indicators are as 
Graph 3. West Java IDI Variable Dynamics, 2014-2015

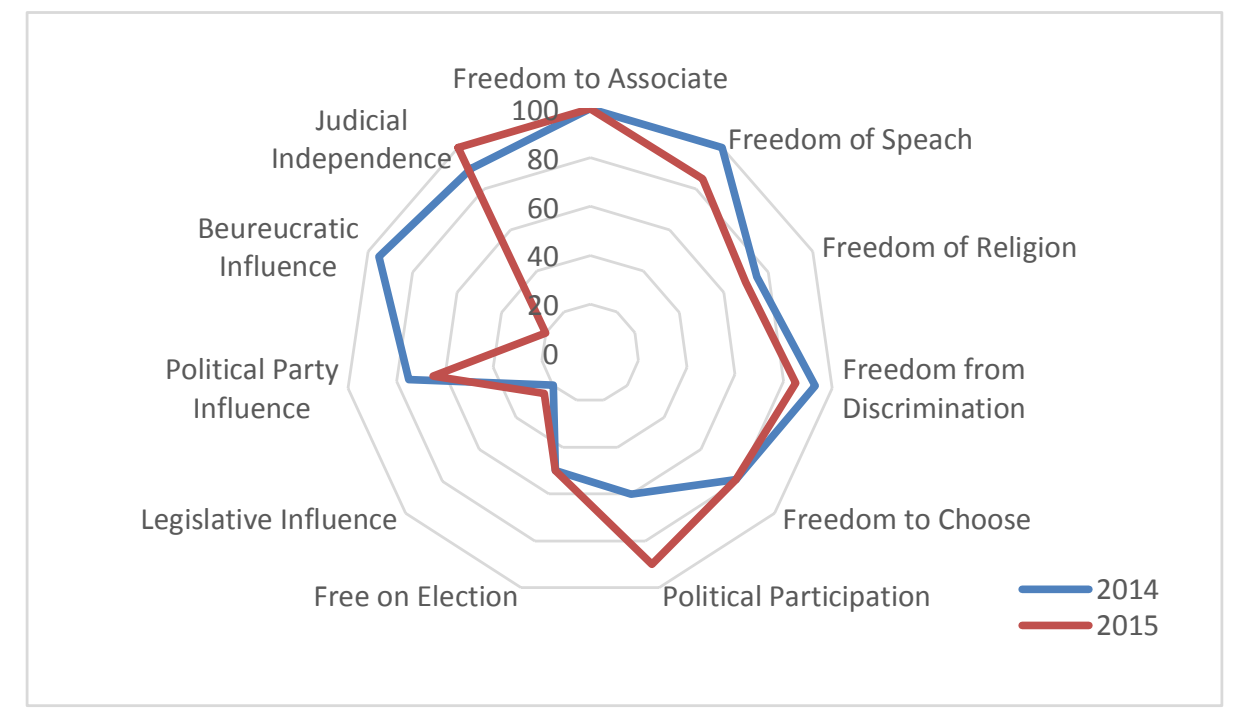

Source: West Java BPS, Official Statistical News No. 46/08/32/Th.XVII, 05 August 2016. West Java Province BPS.

follows. Hampered right of the citizen to the West Java IDI variable index dynamics vote or right to be candidate. Incidents 2014-2015 in graph 3.

that indicate the absence/lack of facilities

From the graph 3 , right to vote and so that the people with access limitations right to be candidate variable in West cannot use their right to vote. The list of Java IDI year 2014 has 74,36 score, fixed voters (Daftar Pemilih Tetap/DPT). while political participation in decisionCitizens who use the right to vote making and supervision variable gets compared to those who have right to vote (voters' turnout). Elected females in 55,87 score. Judging from the scores, the Regional People's Representative right to vote and right to be candidate Assembly (DPRD).

variable gives larger contribution to West Java IDI political rights aspect compared

Political participation variable in decision-making and supervision with demonstration/strike with violence as indicator, and people complaint on governance. As for the two variables and their contribution to the West Java IDI political rights aspect is observable from to political participation in decion-making and supervision variable.

However, the high score of political rights only receives lowest contribution from the indicating event that shows absence/lack of facility so that the people with access limitation cannot use their right to vote. The score from this indicator 
is 60.00. While the other indicator, the accessibility is basically the general hampered right to vote or the right to be guidance or principle for equal general candidate score is 74,36 the quality of election organization.

fixed voter list (DPT) score is 78,15 .

Analysis on the accessibility principle People who use their right to vote is reflected in 2014 general election in compared to people who have right to West Java has features as follows. vote in general election (voters' turnout) Physical accessibility, the availability of score is 71,39 and females elected in DPRD score is 73,33 .

Observing the indicator scores of the political rights fulfillment of the people with disabilities above, then the general election's accessibility principle lies on, as the writer call, "vulnerable indicator group". Especially the "bad" vulnerability, although there is fine line to get into the "moderate" vulnerable. Therefore, the indicator can contribute to the low contribution of political rights aspect to 2014 West Java IDI improvement.

\section{Obstacles of Accessibility Principle Implementation}

The low contribution of citizen political rights to West Java IDI, is inseparable from the accessibility principle implementation in 2014 general election. The general election accessibility is indeed not attached to the political rights, however there should be fulfillment efforts from various sides especially that of the general election authority. The physical facilities to ease the access for the disabled people to give their vote. Nonphysical accessibility, the availability of informational space and political knowledge to build skill and self-reliance or the disabled people political empowerment.

Fixed voter list (DPT) for 2014 general election in West Java contained 33.344.717 people and the number of people who used their voting right reached 23.776.359 people. People who did not use their voting right 9.568.358 persons. Valid vote was 20.985.455 ballots and invalid vote was 2.790.904 ballots. Thus, the overall Jawa Barat citizens who participated in politics reached $71,3 \%$ of the people with right to vote.

According to Head of West Java Province KPU, the percentage shows an increase in West Java citizen political participation if compared to the 2013 West Java Governor Election participation that was only $64 \%$ (Ramadhan, 2014). 
However, from the political participation number of West Java citizen above, it is not certainly known the number of disabled people in 2014 general election DPT. Further, there is no valid report on how many disabled people in the DPT who had used their right to vote.

Head of West Java KPU also admits the fact. B-Trust head, Yuyu Komariah, also acknowledges it. She says, as quoted by Kalimantan.bisnis.com, "Up to today, there is no adequately accurate data to describe the number and detailed characteristics. Especially for the people with disabilities" (Iskandar, 2014).

On the other hand, several estimations emerged before 2013 West Java Governor Election. One of the estimations mentioned the number range between $10 \%-15 \%$ from the total of West Java citizen. Previously, in 2009 the Data and Information Center of Social Department of Republic of Indonesia, released a report on number of disabled people from 9 provinces (Jambi, Bengkulu, Bali, Nusa Tenggara Barat, Nusa Tenggara Timur, Kalimantan Barat, Sulawesi Selatan, Gorontalo and West Java) with the number 299.203 persons are categorized as disabled people. Of the number, West Java is the highest province with disabled people number with $50,90 \%$ of its population (152.294 persons), while the province with lowest number is Gorontalo (1,65\%). Based on the survey, of the total number the $10,5 \%$ (31.327 persons) of them are people with heavy disability who suffer difficulties in completing daily activities (activity daily living/ ADL).

The absence of valid data on the number of people with disability above, either on province level or national level, is admitted by one of the general election authorities in the 2014 general election, Hadar Nafis Gumay, as one of the weak spots of general election organization. He says:

"In fact, we did ask the Committee for Voter Data Update (Pantarlih) to record voters with disabilities. It is in the validation and research process. But we have yet to check again. At the moment, there is no data on disabled voters. The Pantarlih forgot to record the disabled voters when the updating process is ongoing. On the other side, the society seems reluctant to report the disabled voter existence." ${ }^{1}$

Therefore, people with disabilities (along with the older adults) potentials are not receiving proper attention as voter in 2014 general election. The disabled people and older adults need special

\footnotetext{
${ }^{1}$ Salim, Ishak. 2014. Mengenali Diskriminasi Politik Pemilih Difabel. www.kompasiana.com/ accessed 05/05/2018.
} 
approach, treatment and different first thing is related to physical education with other groups. The accessibility, and the second thing is consequence is these two groups are not enjoying equal attention.

nonphysical principle. Nevertheless, apart from receiving support, West Java Province KPU also received challenges

\section{Limited Accessibility Effort}

In the midst of absence of accurate disabled people number in West Java DPT, when approaching the Legislative General Election on 9 April 2014, the West Java KPU as one of the general election authorities actually had done several efforts to implement optimal accessibility principle. One of the efforts was supplying braille template and access on voting sites. The efforts were related to the options the voters can choose. Then, each TPS was designed for the disabled people to use properly. However, KPU only made ballots specially designef for the disabled only for DPD level election and not for the DPR and DPRD. Besides, West Java Province KPU previously carried out several efforts through socialization programs and voting simulation for the disabled people.

The efforts by West Java Province KPU has shown that in the middle regulation and facility limitation the general election accessibility must continue, both when approaching and during the 2014 general election. The from several sides, including from the disabled people.

One of the challenges was a heavy criticism from the Head of West Java Blind Muslim Association. He considered KPU has neglected the secrecy principle out of the four of the general election principles namely direct, general, free, and secret (langsung, umum, bebas, rahasia/Luber) by replacing the braille template usage with companion presence for people with disabilities.

He said: "No matter what, it reduces the secrecy and contradicts with Luber principle. We firmly reject the companion presence although the companion is a family-related in relation. Yudi added, braille template is unnegotiable principle in general election. He said that a distinctive characteristic of self-reliance citizen is to be able to do activities by themselves. Therefore, according to him, if a disabled people are still accompanied by the family or other people that equals dependence (Perdana, 2014).

On the other side, Head of Alumni Association of Social Home Bina Netra 
Wyataguna said by omitting the braille ballots usage (on the DPR, Province DPRD and Regency DPRD) has already shown the KPU incapability. He added, $\mathrm{KPU}$ is doing a discriminative action. He said, as quoted by Kompas.com (25/02/2014), "KPU has violated human rights, especially our right to vote. It is evident, by omitting the voting aid tool which already present in the several previous general election". The absence of voting aid tool at the voting day fro the disabled people will increase the nonvoting potential voters (golongan putih-golput/white group). He argued, every citizen, including disabled people, have the right to participate in political arena. The aiding tool in braille template is also as a form of self-reliance of the disabled in general election participation. He said, "We are forced to say, we don't want to be golput, but KPU forced us to be golput' (Perdana, 2014).

Apart from several challenges, the accessibility principle implementation in political rights fulfillment of the disabled people by West Java Province KPU, both approaching and during the general election, has shown several results. At least the results are reflected in the research conducted by Bandung Trust
Advisory Group (B-Trust). ${ }^{2}$ The research shown 2014 general election in April and July 2014 only participated by 53,7\% of the disabled and older adult people in West Java. The research was carried out through series of activities involving 14.140 people from the disabled and older adult people dispersed in 26 cities/regencies in West Java Province.

The participation number also shown that information knowledge within the disabled people and older adult is categorized into three aspects; information knowledge on how to vote that reaches $78.8 \%$ score, DPT information $74.7 \%$, and legislative election time information 73\%. Besides that, other technical aspects such as ballots number, general election participants, and TPS locations, the number of respondents who have known and not, the total numbers were almost equal. The data shows respondents who have known the TPS location was $55,7 \%$, ballots number was $51,5 \%$, and general election participants as much as 53,7\% (Perdana, 2014).

However, those facts contradicted with the same research above that the accessibility principle implementation effort was still low. Especially when

\footnotetext{
2 Recently, the report is published in book format with the title 'Membangun Kesetaran Berpolitik'.
} 
connected with political rights fulfillment program for the disabled people. Whereas that general election principle imagines for equal and quality general election for every society groups the equal and just general election could manifest in reality (Aspinall and Mietzner, 2010; Olken, 2010). The principle does not only emphasize on nonphysical accessibility like knowledge and political skill improvement of the disabled people, but also physical accessibility such as easiness in getting all the general election property tools, including braille template for any kinds of ballots (Juniar, 2018). And also pick up and other facilities that can support disabled people political participation improvement, both approaching and during the execution. It means the accessibility principle implementation is still limited in 2014 general election.

Limited in this context does not mean that the West Java general election authorities did not do any effort at all. However, as described above, their effort is not optimal due to several obstacles. For that reason, to narrow the gap between the imagined accessibility principle to what is really happening on the field, as the optimization of general election efforts, the Head of West Java
Province KPU sees the importance of general election vitalization and acceleration. Namely, a general election that is friendly to disabled people with equality and justice principles.

Disability friendly general election, as Head of West Java Province KPU argues, should even start from the voter-listing step. For example, through socialization to get voter listing especially on people with disabilities. He also suggests that KPU on regency/city level who are about to hold regional executive election should make social advertisement that is understandable for disabled people. For example, advertisement in braille version so the people with disability can read the material. Including making visual material that contains socialization pictures for intellectually challenged people, and for the television advertisement with sign language.

$\mathrm{He}$ also invites KPU at regency/city level who are going to hold regional executive election to organize technical guidance for the disabled people. The formats of each technical guidance should be differentiated accordingly to the types of disabilities. For example, the technical guidance for the blind people then all the participants should be blind people as well and not be mixed with other kind of 
disabilities. All this time, the participants of technical guidance for the disabled people are mixed from any kinds of disabilities.

Several accessibility principle implementation efforts that have been done and been offered above tend to put the disabled people as objects of access general election. Therefore, there has been no involvement nor empowerment efforts for the disabled people to be the equal subjects with other groups in the society. For example, the empowerment of disabled people in general election planning and execution. They also should be attempted to be a candidate for the people to choose, instead of only choosing for other candidates.

When the political parties make disabled people as their political candidate as representation and interest aggregation of the disabled people, such action could initiate consciousness and volunteerism among the disabled people to go to the voting site/TPS. The offer of accessibility principle improvement effort in general election is essentially not stopping only at the during general election, but also equally emphasized at approaching and post-general election period.

\section{CONCLUSION}

The analysis on practices of disabled people political rights fulfillment in 2014 general election in West Java shows that the general election accessibility principle implementation, physical and nonphysical accessibility, is still limited. It is evident from the real indicator score of disabled people political rights fulfillment that falls into "vulnerable-bad" category. The emergence of vulnerable indicator group is inseparable from these three factors. First, it is vulnerable because the political will and commitment from the general election authorities are not optimum. Second, it is vulnerable because the response from the disabled people community is diverse and tends to be negative. Three, it is vulnerable because the emergence of environmental obstacles such as obstacles from regulations, information and knowledge, also behavior obstacle, and political behavior obstacle.

With that "vulnerable-bad" category, political rights fulfillment, especially in absence/lack of facilities that caused disabled people cannot use their right to vote tends not to give high contribution to the Indonesia Democracy Index of West Java Province in 2014. Contrary, the indicator actually become one of the weak 
points of the index of political rights aspect.

The condition definitely requires more attention and commitment from every stakeholders, especially from the general election authorities. Here lies the importance of accessibility principle implementation strengthening effort. It is perceived as very important because West Java is and will be facing the simultaneous regional election in 2018 , simultaneous general election in 2019, and forthcoming elections.

Efforts should be taken to strengthen the accessibility principle are as follow. First, accessibility principle revitalization in the laws. The accessibility principle, substantially, is not only contained in KPU Regulation but also in the General Election Law itself. So that the accessibility principle would be stronger according to the law and shall be implemented not only during the general election but also at the pre-election and post-election period.

Second, the involvement extension of disabled people on every cycle of general election activities. The disabled people involvement will encourage every strata of the society with disabled people. Until today, the general election authority have only been involving several groups of the disabled people.

Third, the extension in formulation and implementation of policy in creating database of people with disabilities, as a reference for the preparation of voter lists for disabled people (DPOPD). Fourth, supporting capacity improvement and extension for the general election committee, ranging from the central authorities to the voting site level committee whom are sensitive on disabilities issues.

And fifth, encouraging the state and political parties to be more empowering disabled people human resources in every planning and implementation of a number of policies and work program. Political parties along with the government (DPR included) can initiate a political policy such as an affirmative action similar to $30 \%$ quota for female in politics, through General Election Law and Political Party Law design in order to accommodate disabled people into political parties as members or officers also as candidates. For example, $5 \%$ quota of the officers and offered legislative candidates must contain representative from disabled people. Therefore, it is hoped that participation from the disabled people in every general 
election would be improving in quantity and quality.

\section{REFERENCES}

Aspinall, E., \& Mietzner, M. (Eds.). (2010). Problems of democratisation in Indonesia: elections, institutions and society. Institute of Southeast Asian Studies.

Atkinson, V., Aaberg, R., \& Darnolf, S. (2017). Disability Rights and Election Observation: Increasing Access to the Political Process. Nordic Journal of Human Rights, 35(4), 375-391.

Bengtsson, A., \& Christensen, H. (2016). Ideals and actions: Do citizens' patterns of political participation correspond to their conceptions of democracy?. Government and Opposition, 51(2), 234-260.

BPS Provinsi Jawa Barat. 2016. Indeks Demokrasi Indonesia (IDI) Jawa Barat Tahun 2015. Jurnal Berita Resmi Statistik, No. 46/08/32/Th.XVII.

Flinterman, Cees. 1990. Three Generation of Human Rights, dalam Jan Berting et al. (eds). Human Right in a Pluralist Word: Individuals and Collectivies. Westport and London: Meckler.

\section{General Election}

Regulation/Peraturan
Pemilihan Pemilu (PKPU) Number 26 year 2013 on Voting and Vote Calculation on the Voting Site in General Election of People's Representative Assembly, Regional Representative Council, Province Regional People's Representative Assembly, Regency Regional People's Representative Assembly

General Election Committee Regulation/Peraturan Komisi Pemilihan Pemilu (PKPU) Number 5 year 2014 on Alteration on KPU Regulation Number 26 year 2013 on Voting and Vote Calculation on the Voting Site in General Election of People's Representative Assembly, Regional Representative Council, Province Regional People's Representative Assembly, Regency Regional People's Representative Assembly

Halalia, Mugi Riskiana. 2016. Pemenuhan Hak Politik Penyandang Disabilitas Sesuai dengan UndangUndang Nomor 8 Tahun 2016 Tentang Penyandang Disabilitas Oleh Komisi Pemilihan Umum (KPU) Kota Yogyakarta. Yogyakarta: UIN Sunan Kalijaga Yogyakarta. Skripsi.

Hidayat, Yayat. 2016. Aksesbilitas Pemilu Legislatif Tahun 2014 Bagi 
Penyandang Disabilitas di Jawa Juniar, M. W. (2018). Political Barat. Bandung: Universitas Participation for Person with Padjajaran. Disertasi

Hyde, S. D. (2010). Experimenting in democracy promotion: international observers and the 2004 presidential elections in Indonesia. Perspectives on Politics, 8(2), 511-527.

Ibrahim. 2017. Menakar Kedalaman Pengukuran Demokrasi Model Indeks Demokrasi Indonesia (IDI): Beberapa Catatan Subtantif dari Bangka Belitung. Jurnal Masyarakat Kebudayaan dan Politik, FISIP Universitas Airlangga, Surabaya, Vol.30, No.2 tahun 2017, pp 133149.

Iskandar, Yanto Rachmat dan Afif Permana. 2014. Pemilu 2014: Partisipasi Lansia \& Penyandang Cacat Capai 53,7\% di Jabar.

Jarman, M., \& Kafer, A. (2014). Guest editors' introduction: Growing disability studies: Politics of access, politics of collaboration. Disability Studies Quarterly, 34(2).

Junaenah, I. (2015). Indonesia

Democracy Index (IDI): The Effort to Encourage Democratic Provincial Government. International Journal of Social Science and Humanity, 5(5), 466. Disabilities: State's Obligation and Failure. International Journal of Global Community, 1(2, July), 185202.

Law No. 8 year 2012 on DPR, DPD, and DPRD General Election

Law No. 8 year 2016 on People with Disabilities

Law No. 28 year 2002 on Building Construction

Mahan, L. (2018). When the Personal Becomes Political: Infrastructural Violence and Socio-Spatial Exclusion of Persons with Physical Diffabilities in Yogyakarta, Indonesia (Doctoral dissertation).

Merly, Mario. 2015. Aksesibilitas Pemilu 2014 dan Implikasinya Terhadap Ketahanan Politik (Studi Terhadap Persepsi Mahasiswa Penyandang Disabilitasdi Pusat Layanan Difabel UIN Sunan Kalijaga Yogyakarta. Jurnal Ketahanan Nasional, Universitas Gadjah Mada, Vol. 21 No.2, pp. 61-77.

Mietzner, M. (2012). Indonesia's democratic stagnation: anti-reformist elites and resilient civil society. Democratization, 19(2), 209229. 
Olken, B. A. (2010). Direct democracy and local public goods: Evidence from a field experiment in Indonesia. American political science review, 104(2), 243-267.

Perdana, Putra Prima. 2014. Masyarakat Difabel: KPU Memaksa Kami "Golput". Kompas.

Price, R. (2018). Strengthening participation of people with disabilities in leadership roles in developing countries.

Ramadhan, Jatmiko Adhi. 2014. 9,5 Juta Warga Jawa Barat Golput di Pileg 2014. Merdeka News.

Salim, Ishak. 2014. Mengenali Diskriminasi Politik Pemilih Difabel. www.kompasiana.com/ Diakses tanggal 05/05/2018.

Schur, L., Adya, M., \& Ameri, M. (2015). Accessible democracy: reducing voting obstacles for people with disabilities. Election Law Journal, 14(1), 60-65.

Schwarz, A. (2018). A nation in waiting: Indonesia's search for stability. Routledge.

Taufiq, M. 2014. Hasil Studi IDI (Indeks Demokrasi Indonesia) daerah Istimewa Yogyakarta. Academia edu.
Winters, J. A. (2013). Oligarchy and democracy in Indonesia. Indonesia, (96), 11-33. 